\title{
KETERAMPILAN GURU DALAM MENGELOLA KELAS PADA PEMBELAJARAN PRAKARYA DAN KEWIRAUSAHAAN DI SMA NEGERI 1 SINGARAJA
}

\author{
Putu Lidya Suky Parwathi'1), Nyomanm Santiyadnya2), Agus Adiarta ${ }^{3)}$ \\ ${ }^{1}$ Fakultas Teknik dan Kejuruan, Universitas Pendidikan Ganesha (penulis 1) \\ Email: sukyputu@gmail.com \\ ${ }^{2}$ Fakultas Teknik dan Kejuruan, Universitas Pendidikan Ganesha (penulis 2) \\ Email: santiyadnya@yahoo.com \\ ${ }^{3}$ Fakultas Teknik dan Kejuruan, Universitas Pendidikan Ganesha (penulis 3) \\ Email: adiarta pohgending@yahoo.com
}

\begin{abstract}
ABSTRAK
Penelitian ini bertujuan mendeskripsikan keterampilan guru dalam mengelola kelas pada pembelajaran prakarya dan kewirausahaan yang berkaiatan dengan penciptaan, pemeliharaan dan pengembalian kondisi belajar yang optimal serta hambatan dalam mengelola kelas. Metode penelitian yang digunakan, yaitu kualitatif deskriptif. Subjek penelitian ini adalah tiga orang guru mata pelajaran prakarya dan kewirausahaan di SMA Negeri 1 Singaraja. Teknik pengumpulan data yang digunakan, yaitu studi dokumentasi, wawancara terbuka dan observasi. Berdasarkan analisis data, didapatkan hasil sebagai berikut. 1) Guru yang mengajar prakarya dan kewirausahaan baik guru $A$, guru $B$ dan guru $C$ sudah memenuhi keenam variabel pengelolaan kelas efektif. Guru A dan guru C sudah memenuhi $100 \%$ dari pengelolaan kelas efektif sedangankan guru B sudah memenuhi $83 \%$. Jadi guru prakarya dan kewirausahaan di SMA Negeri 1 Singaraja sudah memenuhi 94\% dari pengelolaan kelas efektif. 2) Hambatan guru dalam mengelola kelas pada pembelajran prakarya dan kewirausahaan, yaitu tidak adanya ruang praktikum, kurangnya adanya media dalam pembelajaran, jumlah siswa dalam kelas, jam pelajaran yang berlangsung pada siang hari, banyaknya tugas di pelajaran prakarya dan kewirausahaan dan di pelajaran lain serta alokasi waktu yang sedikit dalam pembelajaran. Saran untuk penelitian selanjutnya sebaiknya dilakukan dengan menggali informasi dari teman sejawat guru yang diteliti dan siswa. Hal ini dilakukan untuk meyakinkan bahwa yang diamati oleh peneliti sesuai dengan apa yang terjadi sebenarnya.
\end{abstract}

Kata Kunci: Keterampilan guru, Mengelola Kelas, Prakarya dan Kewirausahaan

\section{ABSTRACT}

The purpose of this research is to describe the skill of teachers in managing the class on the learning of the workshop and entrepreneurship that related to the creation, maintenance, and the return of the optimum learning condition and the obstacles in managing the class. The method that is used in this research is qualitative descriptive. The subjects in this research are three teachers of workshop and entrepreneurship lessons at SMA N 1 Singaraja. The data collection techniques that are used in this research are documentation study, open interview, and observation. Based on the data analysis, the following results are obtained. 1) Teachers that teach workshop and entrepreneurship such as the teacher $A$, the teacher $B$, and the teacher $C$ have been already satisfied the six variables of the effective classroom management. The teacher $A$ and $C$ have been already satisfied $100 \%$ from the effective classroom management, yet the teacher B has been already satisfied $83 \%$. Therefore, the teachers of workshop and entrepreneurship lessons at SMA N 1 Singaraja have been already satisfied $94 \%$ from the effective classroom management. 2) The teachers' obstacles in managing the class on the learning of workshop and entrepreneurship lessons are there is no practice room, lack of instructional media, the number of students in the class, the lessons that take place during the day, there are a lot of task in workshop and entrepreneurship lessons, and the limit of the time allocation. The suggestion for further research should be done by finding the information from the research colleagues and student colleagues. This is done to ensure that the observed by the researcher in accordance is what actually happened.

Key words: The skill of the teacher, The Class management, workshop and entrepreneurship 


\section{PENDAHULUAN}

Pendidikan

bertujuan untuk mengembangkan bakat dan minat peserta didik dalam segala bidang. Selain itu pendidikan juga bertujuan untuk mengembangkan potensi peserta didik agar menjadi manusia yang beriman dan bertakwa kepada Tuhan Yang Maha Esa, berahlak mulia, sehat, berilmu, cakap, kreatif, mandiri dan menjadi warga negara yang demokratis dan bertanggung jawab. Oleh karena itu perubahan dan perkembangan pendidikan memang harus dilakukan dengan sejalannya perkembangan dunia.

Berbagai upaya telah dilaksanakan pemerintah untuk meningkatkan mutu pendidikan Indonesia, diantaranya dengan dikeluarkannya kurikulum 2013 merupakan kurikulum yang diterapkan oleh pemerintah untuk mengganti Kurikulum Tingkat Satuan Pendidikan (KTSP). Kurikulum 2013 masih dalam masa percobaan dari tahun pelajaran 2013/2014 sampai tahun 2016/2017, dengan menjadikan beberapa sekolah sebagai sekolah piloting (percobaan). Aspek penilaian pada Kurikulum 2013 meliputi 3 aspek, yaitu aspek pengetahuan, aspek keterampilan, serta aspek sikap spiritual dan sosial. Pelaksanaan kegiatan pembelajaran pada kurikulum 2013 ditekankan pada pendekatan saintifik.

Kurikulum 2013, hanya diterapakan pada sekolah yang terpilih menjadi sekolah piloting. Sekolah yang terpilih salah satunya SMA Negeri 1 Singaraja. Sekolah ini sudah menerapkan kurikulum 2013 dari tahun pelajaran 2013/2014. Kurikulum 2013 menekankan pada penggunaan model-model pembelajaran yang lebih inovatif. Pembelajaran inovatif adalah pembelajaran yang bersifat berpusat pada siwa (student center). Pembelajaran ini memberikan kesempatan kepada siswa untuk mengkonstruksi pengetahuan secara mendiri (self directed) dan dimediasi oleh teman sebaya (peer mediated instruction), tetapi bagaimanapun guru tetap memegang peranan penting dalam terjadinya kesuksesan belajar dan pembelajaran karena guru yang merupakan pihak yang langsung berhubungan dengan siswa dalam proses belajar mengajar. Hal tersebut sesuai dengan dengan tugas dan tanggung jawab utama seorang guru yaitu salah satunya melaksanakan kegiatan pembelajaran siswa.

Dalam pelajaran prakarya dan kewirausahaan yang khususnya dibidang rekayasa. Pada pelajaran ini peserta didik tidak hanya diajarkan teori tentang elektronika tetapi juga mengajarkan praktek. Dalam hal ini guru memegang perenan yang sangat penting dalam proses pembelajaran. Jika dilihat dari pembelajaran yang biasanya pelajaran dibidang ini di ajarkan di SMK teknik saja, sedangan anak SMA tidak diajarkan praktek elektronika sebelumnya membuat guru harus bisa membuat pelajaran tersebut tidak membosankan dan menumbuhkan minat belajar siswa. Maka dari itu peran guru sangat penting dalam proses pembelajaran.

Pengelolaan kelas merupakan pola tingkah laku yang kompleks dan guru menggunakannya untuk menciptakan dan mempertahankan kondisi kelas sedemikian rupa sehingga anak didik dapat menciptakan tujuan pengajaran secara efisien dan memungkinkan siswa tetap fokus dalam belajar. Larrives (dalam Allen, 2010) menyatakan pengelolaan kelas adalah satu bagian kritis yang mencampurkan tiga cara strategi mengajar efektif yang meliputi isi materi penuh arti, strategi mengajar dan struktur organisasi untuk mendukung belajar produktif. Selain itu mengelola kelas adalah upaya yang dilakukan oleh guru untuk mengorganisir siswa dalam ruang, waktu dan bahan sedemikian rupa sehingga intruksi isi serta siswa dalam belajar bisa berlangsung. Jadi pengelolaan kelas yang efektif adalah syarat bagi pengajaran yang efektif dan berhasil .

Menurut Syaiful Bahri Djamarah (2005:47) tujuan umum pengelolaan kelas adalah menyediakan dan menggunakna fasilitas kelas untuk bermacam-macam kegiatan belajar dan mengajar, agar mencapai hasil yang baik. Tujuan khusus 
adalah mengembangkan kemampuan siswa dalam menggunakan alat-alat belajar, menyediakan kondisi-kondisi yang memungkinkan siswa bekerja, belajar serta membantu siswa untuk memperoleh hasil yang diharapkan. Dari tujuan umun dan khusus tersebut pengelolaan kelas sangat penting dalam proses belajar mengajar.

Menurut Usman (2005:98) komponen keterampilan mengelola kelas ini pada dasarnya terbagi dua, yaitu :

a) Keterampilan yang berhubungan dengan penciptaan dan pemeliharaan kondisi belajar yang optimal (bersifat preventif). Keterampilan ini berkaiatan dengan kemampuan guru dalam mengambil inisiatif dan mengendalikan pelajaran. Keterampilan ini meliputi beberapa tindakan antara lain sebagai berikut. 1) Menunjukkan Sikap Tanggap, 2) memberi Perhatian, 3) memusatan Perhatian Kelompok, 4) memberikan petunjuk-petunjuk yang jelas, 5) menegur, 6) memberikan penguatan.

b) Keterampilan yang berhubungan dengan pengembalian kondisi belajar yang optimal (bersifat represif). Keterampilan ini berkaitan dengan respon guru terhadap gangguan siswa yang berkelanjutan dengan maksud agar guru dapat mengadakan tindakan remidial untuk mengembalikan kondisi belajar yang optimal. Beberapa startegi yang dapat digunakan oleh guru untuk mengembalikan kondisi yang optimal, yaitu : 1) modifikasi tingkah laku, 2) pendekatan pemecahan masalah kelompok, 3) menemukan dan memecahkan tingkah laku yang menimbulkan masalah.

Tujuan penelitian ini adalah Mendeskripsikan tentang bagaimana keterampilan guru dalam mengelola kelas dan faktor penghambat guru dalam mengelola kelas pada pembelajaran prakarya dan kewirausahaan (rekayasa) di SMA Negeri 1 Singaraja. Keterampilan yang dimaksud adalah keterampilan yang berkaitan dengan penciptaan, pemeliharaan dan pengembalin kondisi belajar yang optimal.

\section{METODE}

Metode yang digunakan dalam penelitian kualitatif deskriptif. Analisis yang digunakan, yaitu analisis kualitatif. Hal ini karena masalah yang diteliti merupakan fenomena secara luas dan mendalam sesuai dengan apa yang terjadi dan berkembang pada situasi sosial mengenai pengelolaan kelas dan hambatan guru dalam mengajar.

Karakteristik penelitian yang dirancang sesuia dengan paradigma penelitian kualitatif yaitu (1) mengamati guru prakarya dan kewirausahaan dalam mengelola kelas di SMA pada keadaan alami dan utuh (holistik kontekstual) sehingga mendapatkan fenomena yang nyata terjadi dikelas, peneliti terjun langsung, sebagai instrumen kunci pengumpulan data; (2) mengkaji data deskriptif dan melakukan verifikasi data yang diperoleh secara empirik pada lokasi penelitian; (3) analisis dilakukan secara deskriptif. Data yang dikumpulkan dan dianalisis secara deskriptif dengan rencangan penelitiannya adalah (1) penelitian pola keterampilan guru dalam mengelola kelas pada pembelajaran; (2) pengumpulan data dilakukan dengan studi dokumentasi, wawancara dan observasi.

Penentuan sumber data penelitian ini juga berdasarkan kriteria sumber data penelitian menurut Sanafiah Faisal (dalam Sugiyono, 2014:303), yaitu (1) mereka yang menguasai atau memahami sesuatu melalui proses enkulturasi, sehingga sesuatu itu bukan sekedar diketahui, tetapi juga dihayatinya. (2) mereka yang tergolong masih sedang berkecimpung atau terlihat pada kegiatan yang tengah diteliti. (3) mereka yang mempunyai waktu yang memadai untuk dimintai informasi. (4) mereka yang tidak cenderung menyampaikan informasi hasil kemasannya sendiri. (5) mereka yang pada mulanya tergolong cukup asing dengan penelitian sehingga lebih menggairahkan untuk dijadikan semacam guru atau narasumber. Sumber dta penelitian ini yaitu 3 orang guru yang mengajar prakarya dan kewirausahaan. 


\section{HASIL DAN PEMBAHASAN}

Berdasarkan pengamatan yang peneliti lakukan, SMA Negeri 1 Singaraja dilengkapi dengan fasilitas yang mendukung proses pembelajaran seperti ruang kelas, ruang perpustakaan, laboratorium fisika, laboratorium kimia, laboratorium biologi, laboratorium komputer, laboratorium bahasa. Jumlah ruang kelas di SMA Negeri 1 Singaraja 33 kelas, dengan 11 kelas $\mathrm{X}, 11$ kelas $\mathrm{XI}$, dan 11 kelas XII. Setiap angkatan ada 9 jurusan IPA, 1 jurusan IPS dan 1 jurusan Bahasa. Fasilitas internet di SMA Negeri 1 Singaraja juga sudah dikembangkan melalui jaringan kabel dan wireless yang dapat diakses dari seluruh lingkungan sekolah.

Secara struktural dan oprasional pelaksanaan penyelenggaraan sekolah dilaksanakan oleh kepala sekolah yang dibantu 4 wakil kepala sekolah. Wakil kepala sekolah memiliki beberapa asisten yang membidangi tugas tertentu. Wakasek kurikulum, wakasek sarana dan prasarana, wakasek kesiswaan, dan wakasek humas. Selain itu, penyelenggaraan sekolah juga dibantu oleh staf pegawai dan guru-guru. Semua komponen tersebut secara bersinergi melaksanakan penyelenggaraan sekolah berdasarkan sistem struktural organisasi yang terdapat di SMA Negeri 1 Singaraja. Penyelenggaraan sekolah diarahkan pada pembangunan fasilitas sekolah baik dari segi fisik maupun nonfisik yang mendukung proses pembelajaran.

Kegiatan belajar di SMA Negeri 1 Singaraja pada hari senin, dimulai pada pukul 07.45 sampai pukul 13.40, yang terbagi dalam 8 jam pelajaran dan 2 kali istirahat. Pada hari selasa sampai kamis dan sabtu kegiatan belajar dimulai pada pukul 07.00 sampai pukul 14.25, yeng terbagi dalam 9 jam pelajaran dan 2 kali istirahat. Pada hari jumat kegiatan belajar dimulai pada pukul 09.35 sampai pukul 11.50, yang terbagi menjadi 3 jam pelajaran dan 1 jam istirahat. Rentang waktu untuk setiap jam pelajaran adalah 45 menit dan untuk waktu istirahat 20 menit. Selain kegiatan belajar SMA Negeri 1 Singaraja juga mengadakan kegiatan literasi, tri sandya dan menyanyikan lagu Indonesia Raya pada pagi hari setiap hari selasa sampai sabtu kecuali jumat pada pukul 06.30 sampai pukul 07.00. Literasi adalah kegiatan membaca di pagi hari kemudian perwakilan siswa dan guru di panggil untuk menyampaikan apa yang dibaca di depan semua siswa dan guru. Pada hari jumat kegiatan tambahan, yaitu jalan santai, ekstrakurikuler dan pembersihan dilanjutkan dengan literasi yang dilakukan pada pukul 06.15 sampai pukul 09.15. Khusus untuk hari raya agama Hindu seperti Purnama dan Tilem yang jatuh setiap 14 sampai 15 hari sekali, serta hari-hari tertentu seperti hari raya Saraswati, persembahyangan bersama dilakukan di Padmasana sekolah menggunakan pakaian adat kecuali yang beragama non Hindu.

Interaksi sosial diantara guru-guru, guru-siswa serta siswa-siswa berlangsung secara harmonis. Hal ini bisa dilihat dari kompaknya kegiatan yang dilakukan setiap harinya. Hubungan antar guru di ruang guru layaknya saudara, saling menyapa, saling membantu dan bercakap-cakap. Hubungan guru dengan siswa juga terlihat harmonis dan tidak ada kesan bahwa siswa takut terhadap guru. Hal tersebut dapat dilihat dari tingkah laku siswa yang tidak sungkan-sungkan bertanya apabila ada hal yang kurang dimengerti baik yang berhubungan dengan pelajaran atau diluar pelajaran. Hubungan antar siswa juga harmonis tidak ada kelompok-kelompokan ataupun otoriter dari kakak kelas terhadap adiknya, namun sebaliknya mereka bersahabat tanpa mengenal kelas, status sosial, ataupun agama. Di SMA Negeri 1 Singaraja juga menganut sistem kakak adik asuh, sehingga antar kakak tingkat dan adik tingkat akan saling membantu, saling bekerja sama dan saling menghormati.

Mata pelajaran prakarya dan kewirausahaan di SMA Negeri 1 Singaraja diampu oleh 3 orang guru. Guru Prakarya dan kewirausahaan di SMA Negeri 1 Singaraja merupakan guru kontrak. Pembagian jam mengajar dibagi sama rata. Jumlah jam pelajaran prakarya dan kewirausahaan di SMA Negeri 1 Singaraja setiap minggunya adalah 2 jam pelajaran untuk kelas XI dan XII. 
Pelaksanaan Pembelajaran prakarya dan kewirausahaan di SMA Negeri 1 Singaraja hanya dapat dilaksanakan di kelas karena tidak adanya ruang praktik yang khusus untuk prakarya dan kewirausahaan dan membuat produk dan alat yang akan digunakan. Sehingga dalam pembuatan produk, siswa yang harus menyediakan alat dan bahannya sendiri. Fasilitas penunjang meliputi LCD proyektor hampir ada disetiap kelas, sehingga mempermudah dalam penggunaannya.

Tabel 1. Pengelolaan kelas yang efektif

\begin{tabular}{|c|c|c|c|c|}
\hline No & Variabel & Guru A & Guru B & Guru C \\
\hline 1. & $\begin{array}{l}\text { Guru } \\
\text { memberikan } \\
\text { tugas dan arahan }\end{array}$ & $\begin{array}{l}\text { Dalam } \\
\text { mengelompokan siswa } \\
\text { dengan melihat } \\
\text { kepintarannya dan } \\
\text { gendernya. Dimana } \\
\text { dalam setiap kelompok } \\
\text { ada yang pintar, } \\
\text { kepintaran sedang dan } \\
\text { kurang pintar. }\end{array}$ & $\begin{array}{l}\text { Dalam mengelompokan } \\
\text { siswa tanpa melihat } \\
\text { kepintaran dan } \\
\text { gendernya. }\end{array}$ & $\begin{array}{l}\text { Dalam } \\
\text { mengelompokan } \\
\text { gendernya. }\end{array}$ \\
\hline 2. & $\begin{array}{l}\text { Guru menjadi } \\
\text { tutor bagi semua } \\
\text { anak dan } \\
\text { kelompok }\end{array}$ & $\begin{array}{l}\text { Mengajak siswa yang } \\
\text { tidak bertanya ikut } \\
\text { memperhatikan } \\
\text { pertanyaan dan } \\
\text { jawaban temannya. }\end{array}$ & $\begin{array}{l}\text { Mengajak siswa yang } \\
\text { tidak bertanya ikut } \\
\text { memperhatikan } \\
\text { pertanyaan dan } \\
\text { jawaban temannya }\end{array}$ & $\begin{array}{l}\text { Mengajak siswa } \\
\text { yang tidak } \\
\text { bertanya ikut } \\
\text { memperhatikan } \\
\text { pertanyaan dan } \\
\text { jawaban } \\
\text { temannya. }\end{array}$ \\
\hline 3. & $\begin{array}{l}\text { Guru mengetahui } \\
\text { perbedaan } \\
\text { masing-masing } \\
\text { individu. }\end{array}$ & $\begin{array}{l}\text { Mengajak siswa } \\
\text { berargumen dan } \\
\text { menerima setiap } \\
\text { argumen siswa }\end{array}$ & $\begin{array}{l}\text { Mengajak siswa } \\
\text { berargumen dan } \\
\text { menerima setiap } \\
\text { argumen siswa }\end{array}$ & $\begin{array}{l}\text { Mengajak siswa } \\
\text { berargumen dan } \\
\text { menerima setiap } \\
\text { argumen siswa }\end{array}$ \\
\hline 4. & $\begin{array}{l}\text { Cara guru } \\
\text { mengatasi } \\
\text { pengaruh buruk } \\
\text { siswa dalam } \\
\text { pembelajaran }\end{array}$ & $\begin{array}{l}\text { Menegur, memberikan } \\
\text { sanksi dan } \\
\text { memodifikasi tingkah } \\
\text { laku dengan cara } \\
\text { melakukan pendekatan } \\
\text { dan memberikan } \\
\text { solusi. }\end{array}$ & $\begin{array}{l}\text { Menegur, memberikan } \\
\text { sanksi dan } \\
\text { memodifikasi tingkah } \\
\text { laku dengan cara } \\
\text { melakukan pendekatan } \\
\text { dan memberikan solusi. }\end{array}$ & $\begin{array}{l}\text { Menegur, } \\
\text { memberikan } \\
\text { sanksi dan } \\
\text { memodifikasi } \\
\text { tingkah laku } \\
\text { dengan cara } \\
\text { melakukan } \\
\text { pendekatan dan } \\
\text { memberikan } \\
\text { solusi. }\end{array}$ \\
\hline 5. & $\begin{array}{l}\text { Hubungan guru } \\
\text { dengan siswa }\end{array}$ & $\begin{array}{l}\text { Menujukan kesiapan } \\
\text { dalam membantu } \\
\text { siswa dengan } \\
\text { mendengarkan } \\
\text { keluhan siswa } \\
\text { terhadap pembelajaran } \\
\text { dan tidak membatasi } \\
\text { waktu siswa untuk } \\
\text { bertanya. }\end{array}$ & $\begin{array}{l}\text { Menunjukan kesiapan } \\
\text { dalam membantu siswa } \\
\text { dengan membantu } \\
\text { siswa jika terjadi } \\
\text { kesusahan dan tidak } \\
\text { membatasi waktu siswa } \\
\text { untuk menghubungi } \\
\text { terkait pelajaran }\end{array}$ & $\begin{array}{l}\text { Menunjukan } \\
\text { kesiapan dalam } \\
\text { membantu siswa } \\
\text { ditunjukan dengan } \\
\text { cara membantu } \\
\text { siswa, jika terjadi } \\
\text { kesusahan dan } \\
\text { tidak membatasi } \\
\text { waktu siswa untuk } \\
\text { menghubungi } \\
\text { terkait pelajaran. }\end{array}$ \\
\hline 6. & $\begin{array}{l}\text { Cara guru } \\
\text { membangkitkan } \\
\text { minat belajar } \\
\text { siswa. }\end{array}$ & $\begin{array}{l}\text { Dengan memberikan } \\
\text { pujian dan nilai } \\
\text { keaktifan. }\end{array}$ & $\begin{array}{l}\text { Dengan memberikan } \\
\text { nilai keaktifan }\end{array}$ & $\begin{array}{l}\text { Dengan } \\
\text { memberikan pujian } \\
\text { dan nilai keaktifan. }\end{array}$ \\
\hline
\end{tabular}


Pengelolaan kelas yang dilakukan
pada pembelajaran prakarya dan kewirausahaan sudah efektif dapat dilihat pada tabel 1. pada tabel ditunjukan guru memberikan tugas dan arahan, guru menjadi tutor untuk semua siswa dan kelompok, guru mengetahui perbedaan masing-masing indivisu, cara mengatasi pengaruh buruk siswa dalam pembelajaran, hubungan guru dengan siswa dan cara membangkitkan minat belajar siswa. Dari keenam indikator guru $A$, guru $B$ dan guru $C$ sudah efektif namun harus ditingkatkan.

Variabel 1, dalam memberikan arahan dan tugas, guru A dan Guru C akan membaginya berdasarkan gender. Setiap kelompok akan dibagi rata baik perempuan maupun laki-laki. Hal ini dilakukan karena dilihat dari minat dan semangat belajar dan dalam pembuatan produk. Perempuan kurang meminati dalam pembuatan alat. Selain itu, pembagian tugas akan menjadi rata jika dilihat dari kemampuan. Guru B akan membabaskan siswa. hal tersebut kurang tepat karena akan terjadi kurangnya tanggung jawab siswa dalam kelompok dan pembagian tugas dalam satu kelompok tidak terbagi rata sesuai kemampuan.

Variabel 2, dalam menjadi tutor untuk semua siswa, baik guru $A$, guru $B$ dan guru $C$ akan membagi perhatiannya kepada semua siswa. Guru akan mengajak siswa yang tidak bertanya untuk ikut memperhatikan pertanyaan dan jawaban siswa. Jadi guru akan memperhatikan semua siswa dalam kelas dan tidak terfokus pada satu siswa.

Variabel 3, ketiga guru akan mengetahui perbedaan masing-masing individu dengan berargumen. Dari argumen siswa guru akan mengetahui apakah siswa tersebut mengerti atau tidak akan pelajaran serta daya serap dalam pembelajaran prakarya dan kewirausahaan.

Variabel 4, cara ketiga guru dalam mengetasi pengaruh buruk dalam pembelajaran dengan menegur dan memodifikasi tingkah. Tahap awal yang dilakukan guru adalah menegur dan jika terus berlajut akan diberikan sanksi. Dalam hal ini guru akan memodifikasi tingkah laku siswa dengan cara pendekatan dan memberikan solusi dari permasalahan siswa.

Variabel 5, hubungan antar guru dan siswa pada pelajaran prakarya dan kewirausahaan sangatlah baik. Dapat dilihat dari kesiapan guru dalam membantu siswa, mendengar keluhan siswa dan tidak membatasi waktu siswa untuk bertanya.

Variabel 6, Dalam membangkitkan minat belajar siswa guru akan memberikan pujian dan nilai keaktifan. Pujian dan nilai keaktifan ini membuat siswa untuk bersemangat dalam menjawab dan menambah nilai.

Hasil penelitian ini juga menunjukan bahwa guru prakarya dan kewirausahaan di SMA Negeri 1 Singaraja memiliki keterampilan-keterampilan mengelola kelas seperti yang dipaparkan pada temuan penelitian, baik yang berhubungan dengan penciptaan dan pemeliharaan kondisi belajar yang optimal (bersifat preventif) maupun keterampilan yang behubungan dengan pengembalian kondisi belajar yang optimal (bersifat represif). Keterampilan-keterampilan pengelolaan kelas yang nampak oleh guru prakarya dan kewirausahaan di SMA Negeri 1 Singaraja adalah mampu menunjukan sikap tanggap, memberi perhatian, memberikan petunjuk-petunjuk yang jelas, memberikan penguatan, memberikan teguran, memperbaiki tingkah laku siswa dan memodifikasi tingkah laku siswa. Menunjukan sikap tanggap guru A dan guru B memperhatikan keadaan siswa yang tidak masuk dipelajaran prakarya dan kewirausahaan. Guru C dalam wawancara dan hasil dokumentasi juga menegaskan dalam pembelajaran pasti melakukan pengecekan atau absen terhadap siswa. komponen ini ditujukan agar siswa merasa guru hadir bersamanya.

Membagi perhatian, guru A dan guru $B$ melakukannya dengan mengajak siswa yang tidak bertanya ikut memperhatikan pertanyaan dan jawabannya. Guru A dan guru B tidak mengabaikan siswa lain melainkan mengajak semua siswa untuk mendengarkan atau merespon pertanyaan temannya. Begitu pula dengan guru C, beliau juga mengajak siswa untuk lebih 
aktif dan tidak fokus pada satu siswa. Guru-guru lebih memilih menggunakan cara verbal dalam membagi perhatian seperti memberi komentar, penjelasan, pertanyaan dan sebagainya terhadap aktivitas siswa.

Keterampilan dalam memusatkan perhatian kelompok guru A melakukannya dengan memberikan siswa yang presentasi untuk menjawab pertanyaan dan memberikan pertanyaan kepada temannya untuk mengetahui apakah temannya mendengarkan apa yang sudah dijelaskan. Selain itu guru A juga ikut mendengarkan dan memberikan penekanan agar pertanyaan tidak meluas dan tetap berada pada topiknya. Guru B dalam observasi kurang memperlihatkan keterampilan memusatkan perhatian kelompok. Guru B kurang memberikan siswa untuk berdiskusi kelompok dalam pembelajarannya. Guru B dan guru C dalam wawancara menyampaikan bila dalam diskusi beliau tidak membatasi siswa. penyataan tersebut kurang tepat, dengan tidak dibatasinya diskusi membuat siswa kurang bertanggung jawab dan waktu akan terbuang sia-sia.

Keterampilan dalam memberikan petujuk-petunjuk yang jelas, guru A dalam pembelajaran presentasi memberitahu siswa untuk satu materi akan dibahas 1 jam pelajaran dan penyampaian tanya jawab juga awalnya yang akan bertanya adalah siswa yang persentasi setelah itu siswa yang kurang mengerti boleh bertanya dan dijawab oleh siswa yang presentasi dan dibantu oleh guru A. Guru $B$ memberikan penjelasan mengenai materi yang akan dibahas dalam pembelajaran sehingga siswa tidak bingung. Guru C dalam memberikan petujuk yang jelas dengan membagikan Lembar Kerja Siswa (LKS) pada saat pembelajaran. Hal ini untuk mempermudah dalam menjelaskan dan memberikan petunjuk.

Keterampilan dalam memberikan teguran dilakukan guru A terhadap siswa yang tidak fokus mendengarkan presentasi dengan memberikan pertanyaan kepada siswa tersebut melalui siswa yang persentasi. Guru B melakukan dengan menegur siswa yang mengerjakan tugas pelajaran lain. Teguran yang dilakukan tidak langsung tertuju kepada satu siswa tersebut tetapi kesemua siswa yang ada dalam kelas. Guru C dalam menegur siswa akan mengajak siswa yang melanggar tata tertib untuk bicara dan memberikan sanksi jika itu dianggap perlu. Teguran dianggap perlu untuk upaya memodifikasi tingkah laku. Agar siswa yang mengganggu pembelajaran tidak melakukan kegiatan yang melanggar lagi.

Keterampilan dalam memberikan penguatan dilakukan guru $A$, guru $B$ dan guru $C$ dengan memberikan nilai berupa keaktifan dan tidak lupa tepuk tangan untuk menghilangkan kejenuhan akibat pelajaran. Memberikan penguatan perlu dilakukan guru dalam pengelolaan kelas. $\mathrm{Hal}$ ini membuat siswa bersemangat dan membuat siswa yang kurang aktif menjadi termotivasi.

Mengatur tempat duduk dan tata ruang yang sesuai dengan startegi yang digunakan, guru A dan guru C tidak melakukannya dalam pembelajaran teori melainkan akan menata ruangan pada saat pembelajaran praktikum, karena dalam praktikum menggunakan ruang kelas. Guru B selalu mengkondisikan ruangan dan siswa sebelum pembelajaran dimulai. Guru B mengajak siswa untuk membersihkan ruangan. Jika ada siswa yang sedang membuat tugas, maka guru $B$ menyarankan untuk menghentikan kegiatan tersebut agar tetap fokus. Penataan kelas hendaknya harus dilakukan setiap pembelajaran. Keindahan dan kebersihan kelas menjadi salah satu kunci keberhasilan pembelajaran. Keadaan kelas yang rapi, bersih dan indah membuat suasana belajar mengajar menjadi menyenangkan

Menentukan alokasi penggunaan waktu belajar mengajar. Guru A dalam membuka pelajaran tidak menyampaikan pembelajaran terdahulu. Guru A langsung menyarankan siswa untuk melakukan presentasi. Guru A membiarkan siswa menjelaskan tentang materi inti terlebih dahulu dan diakhir pelajaran guru A menjelaskan kembali. Menutup pelajaran guru A menjelaskan inti materi yang telah dijelaskan oleh siswa yang presentasi sebelumnya. Guru B membuka pembelajaran dengan membahas 
pembelajaran terdahulu dengan mengajak siswa untuk tanya jawab. Guru B dalam menyampaiakan inti pelajaran mengajak siswa lebih aktif menggali materi tersebut. menutup pelajaran dengan memberikan kesimpulan tidak dilakukan guru pada pembelajran, karena hal tersebut tidak menjadi prioritas. Guru C dalam membuka pelajaran dengan membahas pelajaran terdahulu. Menjelaskan materi inti guru C memberikan LKS untuk mempermudah menyampaikan maksud pembelajaran. Menutup pelajaran guru C mengajak siswa untuk menyimpulkan, bila terjadi kekeliruan guru $\mathrm{C}$ akan memperbaiki dan menambahkan. Menentukan alokasi waktu sangat penting dalam pengelolaan kelas. Dengan adanya alokasi waktu, guru diharapakan bisa membagi waktu baik pendahuluan, inti, dan penutup.

Keterampilan dalam menentukan cara mengorganisasi siswa agar terlibat secara aktif dalam kegiatan belajar mengajar. Guru A dan guru C mengelompokan siswa menurut gendernya dalam melakukan praktikum. Guru A dalam mengkoordinasikan kegiatan diskusi kelompok dengan memberikan semua siswa kesempatan pertanyaan dan menjawab. Guru C mengkoordinasikan dengan memberikan setiap kelompok LKS. Guru B lebih membebaskan siswa, karena bagi guru $B$ pembelajaran prakarya dan kewirausahaan baru dan tetap memerlukan tuntunan dan arahan dalam pembelajarannya. Guru B dalam mengkoordinasikan kelompok lebih memprilakukan semua siswa sama, begitu pula dalam pembuatan alat atau produk. Guru B akan mengarahkan siswa untuk membuat produk yang sama. Dalam hal ini guru A kurang mengefisienkan waktu, karena tidak membuat batasan dalam mengkoordinasikan kelompok. Guru B tidak membuat siswa menjadi kreatif, karena produk yang dibuat sama dan tidak bisa berkreasi. Guru C memberikan siswa kebebasan untuk membagi tugas dengan memberikan siswa LKS.

Keterampilan dalam berinteraki yang baik dengan siswa. Guru A mendengarkan keluhan, pertanyaan dan kesiapan membantu siswa dengan baik. Terlihat dari siswa tidak canggung menanyakan bila ada komponen yang tidak ditemukan dipasaran dan harus diganti dengan komponen apa. Selain itu bila pembelajaran di dalam kelas kurang dan ada siswa yang masih bingung, maka guru A kan menyarankan untuk diskusi diluar jam pelajaran. Guru B menunjukannya dengan menyikapi setiap pertanyaan, karena bagi guru B ungkapan satu orang siswa mewakili siswa yang lain. Jika ada keluhan mengenai pembelajaran guru B akan menggunakan metode lain agar siswa menjadi mengerti dan memahami. Kesiapan membantu siswa ditunjukan guru B dengan memberikan kesempatan kepada siswa untuk menanyakan tugas atau pelajaran diluar kelas baik langsung, melalui telpun atau langsung kerumah guru B. Sama dengan guru $A$ dan guru $B$, guru $C$ juga mendengarkan keluhan dan pertanyaan dengan baik. Guru C melakukan evaluasi pembelajaran melalui pesan kesan diakhir semester untuk mengetahui sudah baik atau tidak cara mengajar. Memberikan kesempatan kepada siswa untuk mencari guru $\mathrm{C}$ diluar pelajaran jika masih kurang mengerti terhadap pelajaran. Interaksi dalam pembelajaran sangatlah penting. Dengan adanya interaksi yang baik guru dengan siswa membuat pembelajaran tidak canggung dan gangguan dalam pembelajaran bisa diatasi.

Ketampilan yang berkaitan dengan pengembalian kondisi belajar yang optimal dilakukan dengan memodifikasi tingkah laku, pendekatan pemecahan masalah kelompok dan menemukan dan memecahkan tingkah laku yang menimbulkan masalah.

Memodifikasi tingkah laku, guru $A$, guru B dan guru $C$ dalam mengubah perilaku siswa yang menyimpang dan memulihkan semangat belajar siswa, akan mengajak siswa tersebut untuk bicara dan memberikan nasehat untuk mengendalikan siswa yang mengganggu proses pembelajaran, ditegur terlebih dahulu, jika masih melakukan hal yang mengganggu tersebut maka akan dikeluarkan dari kelas. Guru B lebih memberi sanksi dengan mengejakan tugas di papan. Guru C akan mengurai nilai kedisiplinan siswa yang mengganggu tersebut. Semua guru sudah melakukan 
memodifikasi tingah laku siswa dengan baik hal ini terlihat dari guru mengejak siswa bicara dan memberikan nasehat, secara tidak langsung guru sudah menganalisis tingkah laku siswa yang mengalami masalah.

Pendekatan pemecahan masalah kelompok. Menciptakan iklim belajar yang demokratis, baik guru $A$, guru $B$ dan guru C memberikan kesempatan siswa unuk bertanya dan menjawab tanpa membatasinya. Dengan demikian siswa akan aktif dalam pembelajaran.

Menemukan dan memecahkan tingkah laku yang menimbulkan masalah. Guru A, guru B dan guru C tidak pernah melakukan penyuluhan atau bimbingan secara khusus. Semua guru melakukannya dengan mengajak bicara dan menasehati. Semua guru saling bekerja sama dalam menyelesaikan permasalahan siswa. Memberikan respon secara positif kepada siswa, guru A akan memberikan sanjungan dan pujian. Guru $B$ dan guru $C$ dengan cara tidak menunjukan kelemahan siswa dan tidak merendahkan siswa.

Guru prakarya dan kewirausahaan di SMA Negeri 1 Singaraja memiliki hambatan dalam pengelolaan kelas yang hampir sama. Pada saat paktik guru mengalami kesulitan dalam proses pembelajaran. Tidak adanya ruang praktikum, membuat guru harus menyulap ruang belajar menjadi ruang praktikum. Akibat dari tidak adanya ruang praktikum, waktu untuk pembelajaran menjadi berkurang, karena siswa harus menyiapakan ruangan dan membersihkan ruangan setelah selesai belajar. Selain ruangan praktikum, media dan alat yang digunakan praktikum juga kurang. Kurangnya media dalam pembelajaran membuat guru sulit menyampaikan maksud pembelajaran yang membuat siswa menghayal. Media merupakan alat yang diperlukan dalam pembelajaran sehingga siswa lebih bersemangat untuk belajar dan tidak bermain dikelas ataupun mengganggu temannya. Hambatan diatas sesuai dengan pendapat yang diungkapkan oleh Aminatul Zahroh (2015:206) media mempunyai arti penting dalam proses belajar mengajar, karena ketidakjelasan bahan atau materi yang akan disampaikan dapat dibantu dengan menghadirikan media.

Dari kurangnya media dan banyaknya siswa yang diajarakan dalam satu ruangan kelas (37 orang) merupakan hambatan yang dimiliki oleh setiap guru. Banyak siswa yang diajarkan dalam satu ruang kelas akan sulit diatur, karena lebih mudah terjadi konflik antara siswa satu dengan yang lain. Keributan akan sering terjadi di dalam kelas jika siswa yang diajar banyak, yang mengakibatkan kondisi belajar mengajar menjadi kurang efektif. hal tersebut dikarenakan masingmasing siswa memiliki karakteristik yang berbeda. Dengan adanya perbedaan karakteristik dari setiap siswa, setiap guru di tuntut untuk mampu membaca dan memahami karakteristik siswa agar lebih mudah dalam mengaturnya. Hambatan diatas sesuai dengan pendapat yang diungkapkan oleh Pidarta (dalam Syaiful Bahri dan Aswan Zain: 2002) masalahmasalah pengelolaan kelas yang berhubungan dengan perilaku siswa adalah reaksi negatif terhadap anggota kelompok, misalnya ribut, bermusuhan, mengucilkan, merendahkan kelompok bodoh dan sebagainya.

Selain itu jam pelajaran yang disiang hari membuat siswa menjadi bosan dan kurang konsentrasi, karena siswa sudah merasa jenuh dengan pelajaran yang sebelumnya. Siswa yang tidak berminat dalam pelajaran akan mengantuk karena suasana yang kurang baik untuk belajar. Banyaknya tugas dari pelajaran lain setelah pelajaran prakarya juga membuat siswa membagi pikirannya sehingga siswa tidak fokus terhadap pelajaran. Hal ini mebuat siswa mencuri waktu untuk mengerjakan tugas pelajaran lain pada jam pelajaran prakarya dan kewirausahaan. Dari penjelasan diatas sesuai dengan didukungnya dengan pendapat Pidarta (Syaiful Bahri Djamarah dan Aswan Zain, 2002:218), bahwa siswa tidak mampu menyesuaikan dengan lingkungan yang berubah, seperti tugastugas tambahan, anggota kelas yang baru, situasi baru dan sebagainya. Selain itu mudah terganggu, misalnya bila di datangi monitor, tamu-tamu, iklim yang berubah dan sebagaianya. 
Setiap guru hambatan lain yang dialamai oleh guru adalah alokasi waktu. Alokasi waktu yang diberikan untuk pelajaran prakarya dan kewirausahaan kurang cukup bagi guru untuk menjelaskan materi yang padat sehingga dalam penyampaiannya, guru harus sedikit cepat dalam menjelaskan. Dengan sedikitnya waktu yang diberikan, guru lebih terfokus terhadap materi yang akan dijelaskan dibandingan dengan pengelolaan kelas. Guru terkadang tidak sempat untuk menyimpulkan materi yang telah dibahas karena kurangnya waktu.

Dari hasil penelitian dan pemaparan di atas, penelitian ini sebatas mendeskripsikan keterampilanketerampilan pengelolaan kelas guru prakarya dan kewirausahaan di SMA Negeri 1 Singaraja dan mendeskripsikan hambatan yang dialami dalam mengelola kelas. Pada penelitian ini, yang dilakukan hanya untuk mengetahui bagaimana keterampilan guru mengelola kelas dan hambatan yang guru alami dalam pembelajaran prakrya dan kewirausahaan. Pengecekan ini bertujuan untuk memastikan derajat kebenaran informasi yang diberikan informan. Perlu dilakukan penelitian yang lebih mendalam untuk mengungkapakan keterampilanketerampilan guru dalam mengelola kelas. Untuk lebih memastikan kebenaran informasi, bisa dilakukan dengan menggali informasi dari teman sejawat guru yang diteliti atau hasil penggalian informasi dari siswa. Hal tersebut dilakukan untuk meyakinkan bahwa apa yang diamati oleh peneliti telah sesuai dengan apa yang terjadi sebenarnya.

\section{SIMPULAN}

Berdasarkan hasil penelitian dan pembahasan dapat disimpulkan hal-hal sebagai berikut:

1) Dari penelitian yang dilakukan menemukan keterampilan guru dalam mengelola kelas pada pembelajaran prakarya dan kewirausahaan di SMA Negeri 1 Singaraja sudah efektif. Guru yang mengajar prakarya dan kewirausahaan baik guru $A$, guru $B$ dan guru $C$ sudah memenuhi keenam variabel pengelolaan kelas efektif. Guru A dan guru $C$ sudah memenuhi $100 \%$ dari pengelolaan kelas efektif sedangankan guru B sudah memenuhi $83 \%$. Jadi guru prakarya dan kewirausahaan di SMA Negeri 1 Singaraja sudah memenuhi $94 \%$ dari pengelolaan kelas efektif.

2) Hambatan guru dalam mengelola kelas pada pembelajran prakarya dan kewirausahaan, yaitu tidak adanya ruang praktikum, kurangnya adanya media dalam pembelajaran, jumlah siswa dalam kelas, jam pelajaran yang berlangsung pada siang hari, banyaknya tugas setelah pelajaran prakarya dan kewirausahaan serta alokasi waktu yang sedikit dalam pembelajaran.

\section{SARAN}

Sesuai dengan temuan dalam penelitian ini, saran yang dapat disampaikan sebagai berikut:

1) Guru diharapkan lebih mendekatakan diri kepada siswa, sehingga tahu permasalahan yang sedang dihadapi siswa. Membagi siswa menjadi beberapa kelompok lebih memudahkan guru dalam mengawasi siswa. kelompok sebaiknya dibagi dengan tepat, agar tidak mengganggu proses pembelajaran.

2) Guru sebaiknya menyiapkan dan menggunakan media dan metode yang sesuai dengan pembelajaran. Hal ini untuk menciptakan semangat belajar siswa dan mengurangi jenuhan siswa.

\section{DAFTAR PUSTAKA}

Allen, K. P. 2010 Classroom Management, Bullying, and Teacher Practices. The Professional Education, 34(1). Tersedia http://wwwtheprofessional educator.org/articles/Allen_final .pdf . Diakses pada 20 April 2017.

Djamarah, Syaiful Bahri. 2005. Guru dan Anak Didik dalam Interaksi Edukatif. Jakarta: PT Rinekla Cipta.

Djamarah, Syaiful Bahri \& Aswan Zain. 2002. Strategi Belajar Mengajar. Jakarta: PT Rinekla Cipta.. 
Sugiyono. 2014. Metode Penelitian Pendidikan: Pendekatan Kuntitatif, Kualitatif, dan R\&D. Bandung: Alfabeta.

Usman. Uzer. 2005. Menjadi Guru Profesional. Bandung: PT Remaja Rosdakarya.

Zahroh Aminatul. 2015. Membangun Kualitas Pembelajaran Melalui Dimensi Profesionalisme Guru. Bandung: Yrama Widya. 